\title{
Cation Channel Blocker
}

National Cancer Institute

\section{Source}

National Cancer Institute. Cation Channel Blocker. NCI Thesaurus. Code C93038.

A group of agents that block the influx or efflux of positively charged ions through cell membrane. 